\title{
IMPLEMENTASI SISTEM INFORMASI MANAJEMEN DALAM MENDUKUNG PELAYANAN ADMINISTRASI DI SMA NEGERI 1 BARRU
}

\author{
${ }^{1}$ Musdalifah, ${ }^{2}$ Nasir Mahmud, ${ }^{3}$ Kasmawati \\ ${ }^{1}$ Universitas Islam Negeri Alauddin Makassar \\ 2Universitas Islam Negeri Alauddin Makassar \\ ${ }^{3}$ Universitas Islam Negeri Alauddin Makassar \\ E-mail: musdalifahmpi@gmail.com
}

\begin{abstract}
This study aimed to determine the implementation of system information management and administrative services at SMA Negeri 1 Barru. This research is a field research using qualitative methods and qualitative approaches. Data collection techniques used were interviews and observation. The results showed that the application of management information systems in supporting administrative services at SMA Negeri 1 Barru had been well implemented by utilizing all facilities and infrastructure facilities as a foothold in optimizing the application of system information management.
\end{abstract}

Keywords: System Information Management, Administrative Services

\begin{abstract}
Abstrak
Penelitian ini ditujukan untuk mengetahui implementasi sistem informasi dan pelayanan administrasi manajemen di SMA Negeri 1 Barru. Penelitian ini ialah penelitian lapangan yang menggunakan metode penelitian kualitatif. Teknik pengumpulan data yang digunakan ialah wawancara dan observasi. Hasil penelitian menunjukkan bahwa penerapan system informasi manajemen dalam mendukung pelayanan administrasi di SMA Negeri Barru telah terlaksana dengan baik dengan memanfaatkan segala fasilitas sarana dan prasarana sebagai pijakan dalam optimalisasi penerapan system informasi manajemen.
\end{abstract}

Kata Kunci: Sistem Informasi Manajemen, Pelayanan Administrasi

\section{PENDAHULUAN}

Seiring dengan perkembangan ilmu pengetahuan, informasi, dan teknologi komunikasi menjadikan kamajuan ilmu pengetahuan diberbagai bidang seperti perusahaan ataupun organisasi, tanpa kecuali pada bidang pendidikan. Keberadaan dan peran teknologi informasi telah membawa era baru dalam perkembangan pendidikan tetapi belum diimbangi dengan peningkatan sumber daya manusia.

Sarwono menyatakan bahwa maju dan berkembangnya peradaban dunia juga mempengaruhi alat pendukungnya, diantaranya adalah teknologi komunikasi yang penggunaanya sebagai alat bantu untuk memproses dan mentransfer perangkat data informasi yang dibutuhkan, teknologi komunikasi pula sebagai 
sebab masuknya norma dan nilai baru dari luar yang pada gilirannya norma dan nilai baru ini masuk ke dalam lingkungan kehidupan keluarga dan masyarakat. ${ }^{1}$

Era baru dalam dunia pendidikan, yaitu diperlukannya reformasi pendidikan yang berkaitan erat dengan sistem informasi yang dibutuhkan dalam pengembangan dunia pendidikan. Konsep ini memiliki nuansa bagaimana dunia pendidikan berusaha menggunakan perangkat komputer, yang dapat di aplikasikan sebagai sarana komunikasi untuk meningkatkan kinerja dunia pendidikan secara signifikan.

Peningkatan kinerja pendidikan dimasa yang akan datang memerlukan sistem informasi dan teknologi informasi yang tidak hanya berfungsi sebagai pendukung keberhasilan pendidikan, akan tetapi sebagai faktor utama dalam mendukung dunia pendidikan sehingga mampu bersaing dipasar global. Dengan pengetahuan yang diperoleh, lembaga pendidikan telah memunculkan konsep dan strategi baru dalam memberikan layanan pada pengguna jasa pendidikan yang kemudian diterapkan dalam praktik oleh beberapa lembaga pendidikan yang mempunyai peluang untuk memanfaatkan konsep dan strategi tersebut. ${ }^{2}$

Pendidikan pada saat ini membutuhkan dasar yang harus dibangun, yaitu menyadari posisi sebagai penghasil jasa pendidikan, lembaga pendidikan harus memahami dengan baik kebutuhan masyarakat yang makin kompleks terutama diikuti pengembangan teknologi pendidikan yang sangat pesat. Strategi paling tepat untuk meningkatkan mutu pendidikan adalah memberikan layanan pendidikan dengan memfasilitasi praktek pembelajaran dengan menggunakan infrastruktur teknologi, seperti fasilitas belajar dengan memadukan komputer.

Pemanfaatan konsep dan strategi yang digunakan dalam memberikan layanan pada lembaga pendidikan berupa informasi. Aplikasi pengolahan informasi dalam berbagai bidang sering disebut dengan istilah MIS (Management Information System) atau SIM (Sistem Informasi Manajemen). Sistem Informasi Manajemen adalah serangkaian sub sistem informasi yang menyeluruh dan terkoordinasi dan secara rasional terpadu yang mampu mentransformasi data sehingga menjadi informasi lewat serangkaian cara guna meningkatkan produktivitas atas dasar kriteria mutu yang telah ditetapkan.

Ada beberapa faktor yang menjadikan sistem informasi manajamen sangat dibutuhkan kepala sekolah, diantaranya adalah kepala sekolah dihadapkan pada lingkungan global yang semakin canggih dan lingkungan pendidikan semakin rumit dan dinamis. Dengan segala kerumitan, kepala

\footnotetext{
${ }^{1}$ Sarlito W. Sarwono, Psikologi Remaja (Cet. XIII; Jakarta: Raja Grafindo, 2010), h. 139.

${ }^{2}$ Eti Rochaety, Pontjorini Rahayuningsih, Prima Gusti Yanthi, Sistem Informasi Manajemen Pendidikan, Jakarta: Bumi Aksara, 2006). 85
} 
sekolah dituntut untuk membuat keputusan dengan cepat sebagai penentu kebijakan. Sistem informasi manajemen pada lembaga pendidikan adalah sistem yang didesain untuk kebutuhan manajemen dalam upaya mendukung fungsi-fungsi dan aktivitas manajemen pada suatu organisasi pendidikan.

Maksud diterapkannya sistem informasi manajemen pada lembaga pendidikan adalah sebagai pendukung kegiatan fungsi manajemen; planning, organizing, staffing, directing, evaluating, coordinating, dan budgeting 3 dalam rangka menunjang tercapainya sasaran dan tujuan fungsi-fungsi operasional dalam organisasi pendidikan. Dengan adanya sistem informasi manajemen lembaga pendidikan akan merasakan beberapa manfaat sebagai berikut, pertama, tersedianya sistem pengeloaan data dan informasi pendidikan. Kedua, terintegrasinya data dan informasi pendidikan untuk mendukung proses pengambilan keputusan. Ketiga, tersedianya data dan informasi pendidikan yang lengkap bagi seluruh stakholders yang berkepentingan dalam bidang pendidikan.

Selain itu, penerapan Sistem informasi manajemen pada lembaga pendidkan berfungsi sebagai alat bantu pengambil keputusan dan oleh pihak lain yang tergabung dalam inter-organizational information system sehingga organisasi pendidikan dapat berinteraksi dengan pihak berkepentingan (stakeholders).

Pengembangan sistem informasi manajemen pada lembaga pendidikan sangat dibutuhkan, karena dalam menghadapi persaingan global lembaga pendidikan dituntut untuk memberikan informasi lebih cepat, akurat dan nyaman yang merupakan bagian dari kualitas pelayanan, sehingga akan menjadi sebuah keunggulan bersaing (competitive advantage). ${ }^{4}$

Penggunaan sistem informasi manajemen sekolah tidak hanya sebagai proses otomatisasi terhadap akses informasi, tetapi juga menciptakan ketepatan, kecepatan, dan kelengkapan sebuah sistem yang terintegrasi, sehingga proses organisasi akan berjalan dengan efisien (berhasil guna), terukur dan fleksibel (luwes, tidak kaku).

Demi kepentingan pendidikan hendaknya sekolah mendesain segala hal yang berhubungan dengan kebutuhan siswa di sekolah sesuai dengan perkembangan zaman. Sekolah yang melakukan pelayanan terhadap siswa sangat membutuhkan kehadiran teknologi informasi sebagai pendukung peningkatan kualitas pelayanan dimana menyediakan program layanan siswa yang mudah dicapai dan lengkap.

\footnotetext{
${ }^{3}$ T Hani Handoko, Manajemen, (Yogyakarta; BPFE-YOGYAKARTA, 1999). 23

${ }^{4}$ Eti Rochaety, Pontjorini Rahayuningsih, Prima Gusti Yanthi, Sistem Informasi Manajemen Pendidikan, Jakarta: Bumi Aksara, 2006) 15
} 
Demi memenuhi segala hal yang berhubungan dengan kepentingan siswa, dalam menjalankan tugasnya kepala sekolah mendesain dan menyediakan program layanan sekolah yang terdiri dari dua jenis, yaitu: layanan pokok dan layanan bantu. Yang berhubungan dengan layanan pokok kepala sekolah dibantu oleh empat personil, diantaranya adalah personil pelayanan pengajaran, personil pelayanan administrasi, personil pelayanan fasilitas sekolah, dan personil pelayan murid (siswa). ${ }^{5}$ Sedangkan yang berhubungan dengan layanan bantu, kepala sekolah menyediakan layanan berupa: layanan perpustakaan, layanan bimbingan dan konseling, serta layanan kesehatan dan keamanan.

Dalam hal ini kepala sekolah juga memanfaatkan sistem informasi manajemen, dengan sistem informasi manajemen yang terus berkembang lembaga pendidikan dapat bekerja secara cepat dan akurat sehingga produktivitas kerja di lembaga pendidikan lebih meningkat dan berdampak pada meningkatnya mutu pendidikan.

Sekolah SMA Negeri 1 Barru ini diharapkan dapat mengantisipasi program dan layanan pendidikan yang mampu bersaing dan bersanding dengan sekolah internasional serta handal dalam menghadapi era global maupun memenuhi tuntutan kebutuhan pembangunan lokal dan nasional.

Pada hal ini, peneliti akan menelusuri lebih dalam sekolah SMA Negeri 1 Barru sebagai objek penelitian, dengan alasan karena SMA Negeri 1 Barru menyadari pentingnya praktek sistem informasi yang dipadukan dengan kemajuan teknologi informasi yang dikembangkan di dalam sistem informasi yang handal dalam meningkatkan mutu pendidikan, sehingga menghasilkan informasi yang akurat, up to date dan dapat dinikmati oleh semua pengguna jasa pendidikan dan menjadikan keunggulan dalam memberikan layanan jasa pendidikan.

\section{METODE}

Penelitian ini merupakan penelitian lapangan dengan menggunakan pendekatan dan desain penelitian kualitatif. Penelitian berfokus pada SMA Negeri 1 Barru, dengan menjadikan kepala sekolah, guru, siswa dan pegawai sebagai sumber data. Data dikumpulkan menggunakan teknik wawancara dan observasi, serta dokumentasi sebagai pelengkap data. Data dianalisis menggunakan teknik analisis deskriptif melalui tiga alur, yakni reduksi data, penyajian data, dan verifikasi (kesimpulan).

\footnotetext{
${ }^{5}$ Oteng Sutrisno, Administrasi Pendidikan, (Bandung: Angkasa, 1985), h. 65.
} 


\section{PENERAPAN SISTEM INFORMASI MANAJEMEN}

Teknologi telah memberikan kemudahan bagi kita dalam kehidupan ini, hampir setiap aspek kehidupan sudah memanfaatkan kecanggihan teknologi. Beberapa fasilitas teknologi dimanfaatkan di antaranya untuk mempermudah komunikasi atau untuk mendapatkan informasi. Kemajuan teknologi informasi tidak dapat dilepaskan dari bidang pendidikan dan pelayanan.

Strategi paling tepat untuk meningkatkan mutu pendidikan adalah memberikan layanan pendidikan. Sekolah yang melakukan pelayanan terhadap siswa sangat membutuhkan yang namanya teknologi informasi sebagai pendukung peningkatan kualitas pelayanan yaitu aplikasi pengolahan informasi dalam berbagai bidang sering disebut dengan istilah MIS (Management Information System) atau SIM (Sistem Informasi Manajemen).

Sistem informasi manajemen pada lembaga pendidikan memberikan informasi lebih cepat, akurat dan nyaman yang merupakan bagian dari kualitas pelayanan, sehingga akan menjadi sebuah keunggulan bersaing. Dimana aplikasi pengolahan data yang digunakan melalui dapodik sehingga memudahkan tenaga administrasi untuk mengolah data baik data siswa, guru, sarana prasarana, dan keuangan dan sebagainya.

Sistem informasi manajemen yang dipahami oleh sekolah adalah suatu sistem yang berorientasi kepada sistem informasi yang mementingkan keakuratan data dan ketepatan sasaran dalam memperoleh berbagai data dan informasi yang dibutuhkan sekolah. Informasi yang dibutuhkan seperti sarana prasarana, pembiyaan, pengelolaan, kompetensi lulusan, penilaian, standar isi, pendidik dan tenaga kependidikan. Adapun sistem pengolah data yang digunakan disini yaitu DAPODIK yang meliputi data guru, tenaga kependidikan, data siswa, data sarana prasarana dan sebagainya yang secara cepat dan valid di sampaikan kepada instansi terkait seperti ke Dinas Pendidikan Kabupaten/Kota maupun ke Kementrian Pendidikan Nasional. ${ }^{6}$

\footnotetext{
${ }^{6}$ Abdul Majid Rahmat, Kepala Sekolah SMA Negeri 1 Barru, Wawancara oleh peneliti, dalam Ruangan Kepala Sekolah, Barru, 02 juni 2016.
} 


\section{Gambar 1}

\section{Aplikasi Pengolah Data yaitu Dapodik}

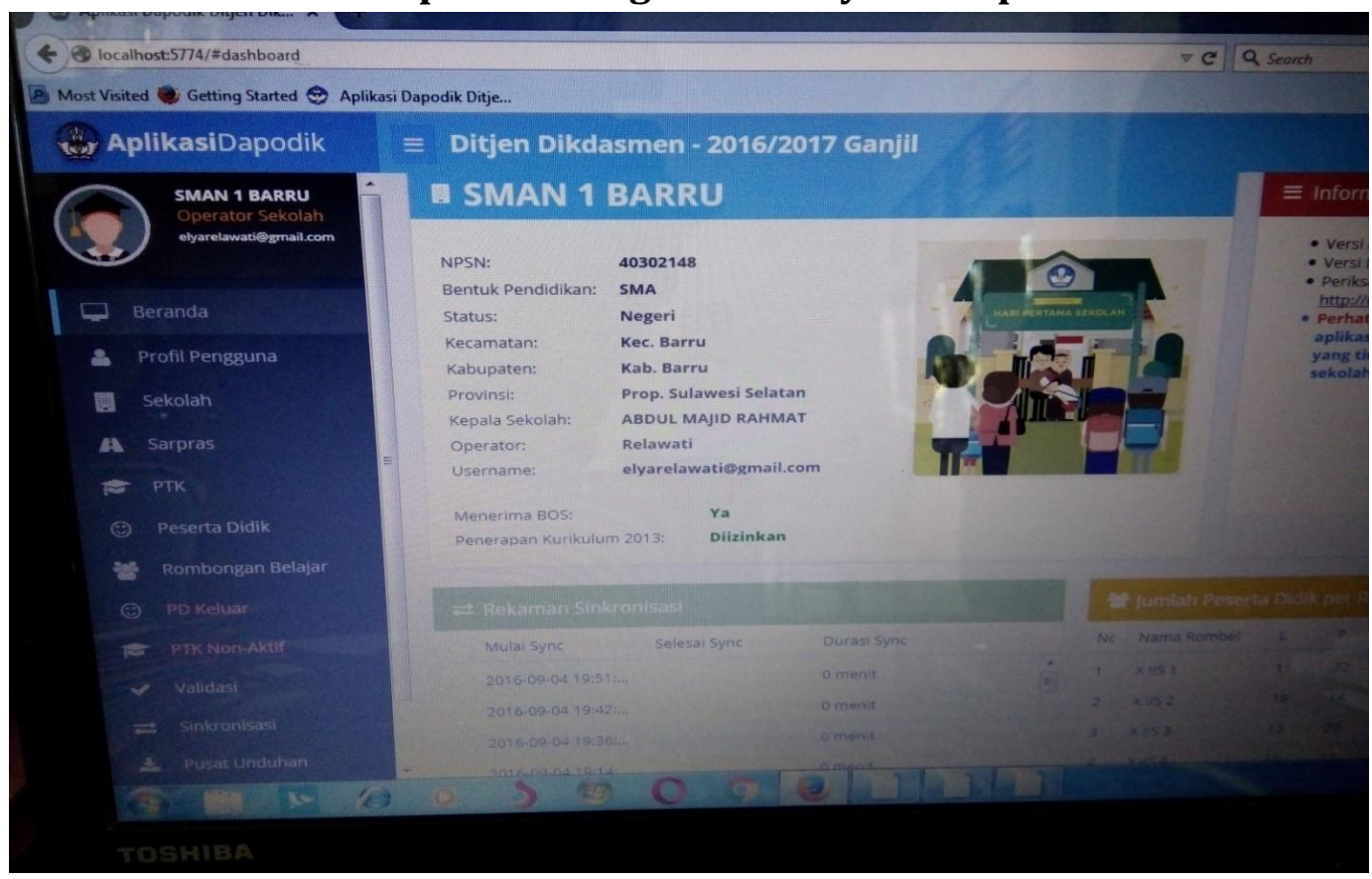

Kepala sekolah memiliki peran dan tanggung jawab sebagai manajer dalam menentukan arah suatu pendidikan ke depan tentunya kepala sekolah sebagai top leader yang mempunyai peran utama dimana demi memenuhi segala hal yang berhubungan dengan kepentingan siswa, dalam menjalankan tugasnya kepala sekolah mendesain dan menyediakan program layanan sekolah. Salah satunya menerapkan sistem informasi, dimana pengolahan data menggunakan dapodik sehingga memudahkan tenaga administrasi untuk mengolah data baik data siswa, guru, sarana prasarana, keuangan dsb, yang akan dilaporkan ke pusat.

Adapun yang bertindak sebagai pelaksana Sistem informasi manajemen yaitu wakil kepala sekolah yang terdiri atas empat personil seperti wakasek bagian pengajaran, kesiswaan, sarana prasarana, dan humas. Yang dibagi misalnya dari kesiswaan yaitu seluruh siswa diinput datanya mulai dari data riwayat pendidikan, status keluarganya kemudian semua itu di masukkan dalam sebuah sistem dapodik yang dikoordinir oleh operator sekolah. ${ }^{7}$

Sekolah SMA Negeri 1 Barru ini yang bertindak sebagai ketua Sistem Informasi Manajemen yaitu kepala sekolah sekaligus penanggung jawab dan yang bertindak sebagai pelaksana Sistem Informasi Manajemen yaitu wakil

${ }^{7}$ Sitti Nurhayati, Guru SMA Negeri 1 Barru, Wawancara oleh peneliti, dalam Tata Usaha, Barru, 03 juni 2016 
kepala sekolah yang terdiri atas empat personil seperti wakasek bagian pengajaran, kesiswaan, sarana prasarana, dan humas.

Selain itu di sekolah SMA Negeri 1 Barru ini dimana kepala sekolah sebagai top leader mempunyai peran yang utama dimana beliau juga memberikan pelayanan kepada siswa dalam hal pemanfaatan Teknologi informasi melalui penggunaan wifi atau jaringan internet, siswa diarahkan untuk membuat blog sehingga memudahkan siswa untuk mengakses informasi, memperluas wawasan, mengenal teknologi informasi atau mencari beasiswa dari luar.

Salah satu pelayanan yang ditawarkan kepala sekolah yaitu dengan pemanfaatan teknologi informasi melalui penggunaan wifi atau jaringan internet dimana siswa diarahkan menggunakan blog yang dapat mengakses informasi yang dibutuhkan agar menjadikan mereka kreatif dan mengurangi dampak nongkrong atau perkumpulan yang tidak bermanfaat. Dengan memanfaatkan blog tersebut siswa terbiasa menulis dan menggunakan teknologi dalam menjalani kehidupan. ${ }^{8}$

Sekolah telah menyediakan wifi atau jaringan internet disetiap tempat misalnya di ruangan dimana kita diarahkan menggunakan blog atau e-mail. Itu salah satu hal yang baik dalam pemberikan pelayanan kepada kami dimana dengan penggunaan wifi tersebut kita bisa mengirimkan tugas yang diberikan oleh guru tanpa harus bertatap muka langsung melalui blog atau email tersebut. Dengan menjelajah internet, kita akan tahu banyak hal yang bisa di dapat melalui internet seperti mencari artikel yang berkaitan dengan mata pelajaran di sekolah. Ini semua sangat menunjang sekali terhadap proses belajar di sekolah.

Demikian manfaat yang diperoleh siswa dari penggunaan wifi atau jaringan internet sekolah yaitu:

1. Mempermudah mengerjakan tugas

2. Tidak membosankan dalam proses pembelajaran

3. Membuka cakrawala pemikiran siswa

4. Siswa lebih aktif dan semangat

5. Siswa dapat berkreasi membuat blog/email dll

6. Siswa dapat memantau ilmu dari luar sekolah

7. Siswa dapat mencari info beasiswa dari dalam / luar negeri. ${ }^{9}$

Kegiatan dalam lingkungan sekolah terutama dalam kegiatan belajar mengajar, sistem informasi manajemen sangat dibutuhkan tentu saja dengan dukungan teknologi yang semakin maju dengan penggunakan fasilitas

${ }^{8}$ Sitti Nurhayati, Guru SMA Negeri 1 Barru, Wawancara oleh peneliti, dalam Ruangan Tata usaha, Barru, 03 juni 2016.

${ }^{9}$ Ulwiah, Siswa SMA Negeri 1 Barru, Wawancara oleh peneliti, di Taman Sekolah, Barru 032016. 
komputer, penggunaan wifi atau jaringan internet. Semua kegiatan sekolah lebih menguntungkan dalam menunjang proses belajar di sekolah.

SMA Negeri 1 Barru juga menyediakan akses informasi mengenai status sekolah, peran sekolah yang perlu dikembangkan, nilai tambah sekolah kepada masyarakat semuanya itu bisa di akses melalui website sekolah ini yaitu : http://www.sman1barru.com

\section{Gambar 2}

\section{Website SMA Negeri 1 Barru}

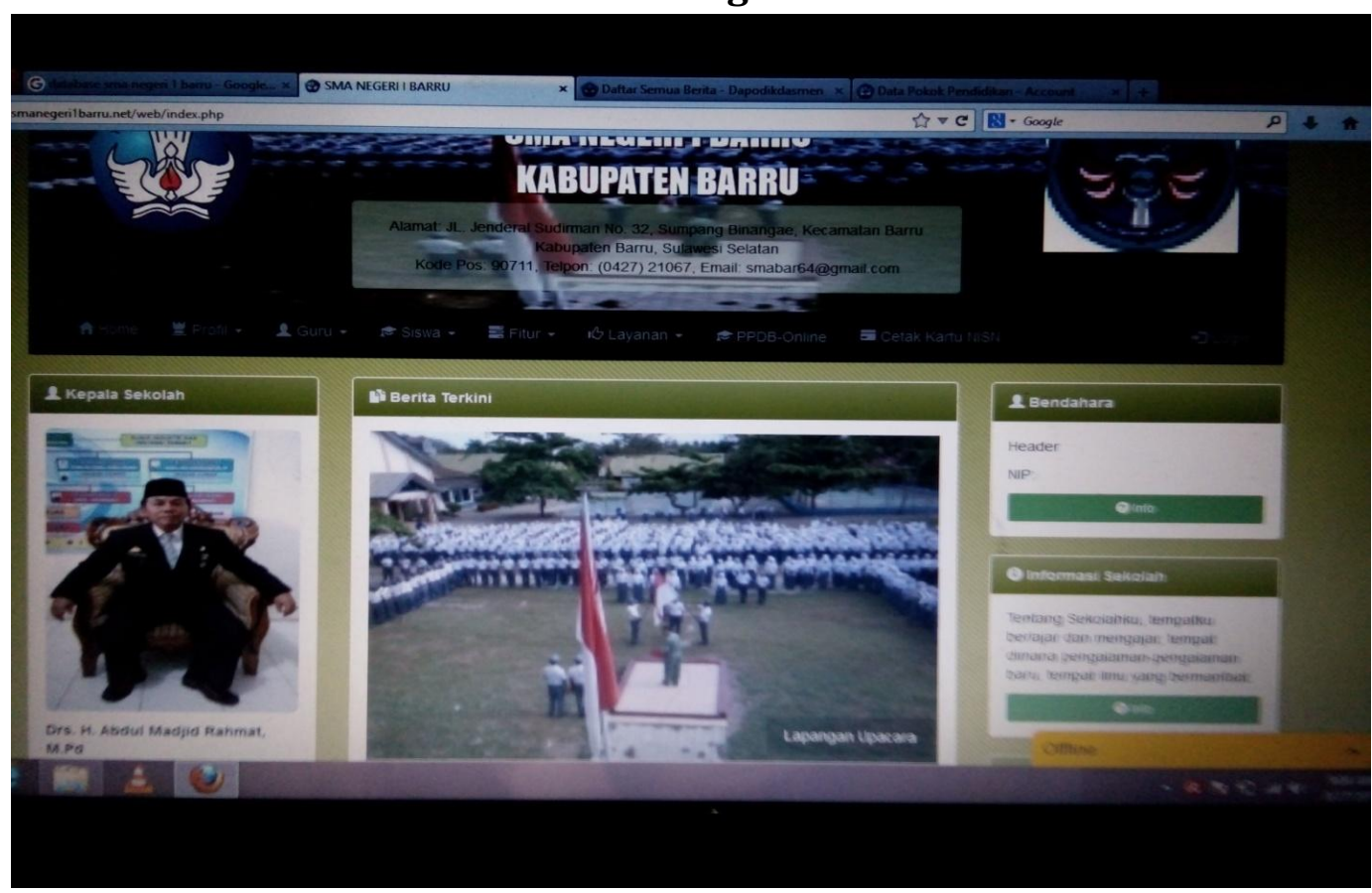

Dengan diterapkananya sistem informasi manajemen di sekolah dapat dijadikan sebagai salah satu dasar dalam meningkatkan mutu pendidikan dimana dalam memberikan kesempatan kepada guru dan pengurus sekolah untuk meningkatkan kualitas komunikasi dan pembinaan kepada siswa. Siswa akan lebih berkesempatan mengembangkan kepribadian dan pengetahuannya. Misalnya penggunaan teknologi dengan memfasilitasi praktek pembelajaran dengan memadukan komputer, penggunaan wifi atau jaringan internet Jadi, ketika dalam proses belajar mengajar akan menciptakan suasana yang efektif, mereka dapat dengan mudah mengerjakan tugas, dalam proses belajar mengajar tidak membosankan, siswa lebih aktif dan semangat belajarnya. ${ }^{10}$

Sehubungan dengan hal tersebut maka dapat dikatakan bahwa salah satu yang ditawarkan kepala sekolah yaitu Sistem Informasi Manajemen yang

\footnotetext{
${ }^{10}$ Sitti Nurhayati, Guru SMA Negeri 1 Barru, Wawancara oleh peneliti, dalam Ruangan Tata Usaha, Barru, 03 juni 2016.
} 
akan diimplementasikan dalam bentuk alat pemrosesan data sekolah yaitu dapodik yang meliputi data siswa, guru, sarana prasarana dan keuangan dan sebagainya.

Kepala sekolah juga menyediakan berupa perangkat lunak berbasiskan web. Hal tersebut dimaksudkan untuk menunjang kegiatankegiatan sekolah, yang mempunyai tujuan sebagai berikut:

1. Tersedianya Informasi untuk mendukung perencanaan dan pengambilan keputusan bagi kepentingan sekolah ke depan.

2. Tersedianya layanan informasi bagi komunitas sekolah seperti guru, siswa, staf, pimpinan, orang tua, alumni dan masyarakat pada umumnya.

3. Memberikan nilai tambah bagi profil sekolah sehingga bisa meningkatkan daya saing yang lebih baik.

Berdasarkan semua pernyataan informan di atas, maka peneliti dapat menarik kesimpulan bahwa penerapan sistem informasi manajemen pada lembaga pendidikan sangat dibutuhkan, karena dalam menghadapi persaingan global lembaga pendidikan dituntut untuk memberikan informasi lebih cepat, akurat dan nyaman yang merupakan bagian dari kualitas pelayanan, sehingga akan menjadi sebuah keunggulan bersaing.

\section{LAYANAN ADMINISTRASI}

Dalam rangka menunjang kelancaran proses belajar mengajar di instansi sekolah diperlukan suatu bagian yang mendukung kegiatan tersebut yaitu Ketatausahaan. Dengan berkembangnya zaman yang sekarang lebih dikenal dengan era globalisasi, fungsi tata usaha harus lebih dapat ditingkatkan kualitasnya tentang teknologi terutama teknologi informasi ataupun lebih dikenal dengan era komputerisasi. Hal ini dimaksud untuk lebih mengefektifkan pekerjaan dan untuk memberikan pelayanan yang lebih baik. Oleh karena itu setiap staf tata usaha diharuskan menguasai teknologi tersebut.

Keberadaan ketatausahaan disetiap instansi sangat berperan penting untuk kelancaran kegiatan dan perkembangan instansi yang bersangkutan dan dengan perkembangan zaman teknologi informasi dapat lebih mengefektifkan kinerja dari tata usaha itu sendiri.

Demi kelancaran kegiatan dalam sistem informasi manajemen terdapat bagian-bagian yang bertugas mengkoordinir pada semua bagian dan bertanggung jawab langsung pada manajemen puncak/kepala sekolah yang meliputi bagian pengumpulan data, bagian penginputan data, bagian penyimpanan data, semuanya itu dikerjakan oleh tata usaha khususnya operator sekolah. 


\section{Gambar 3}

Tata Usaha Selaku Operator Sekolah

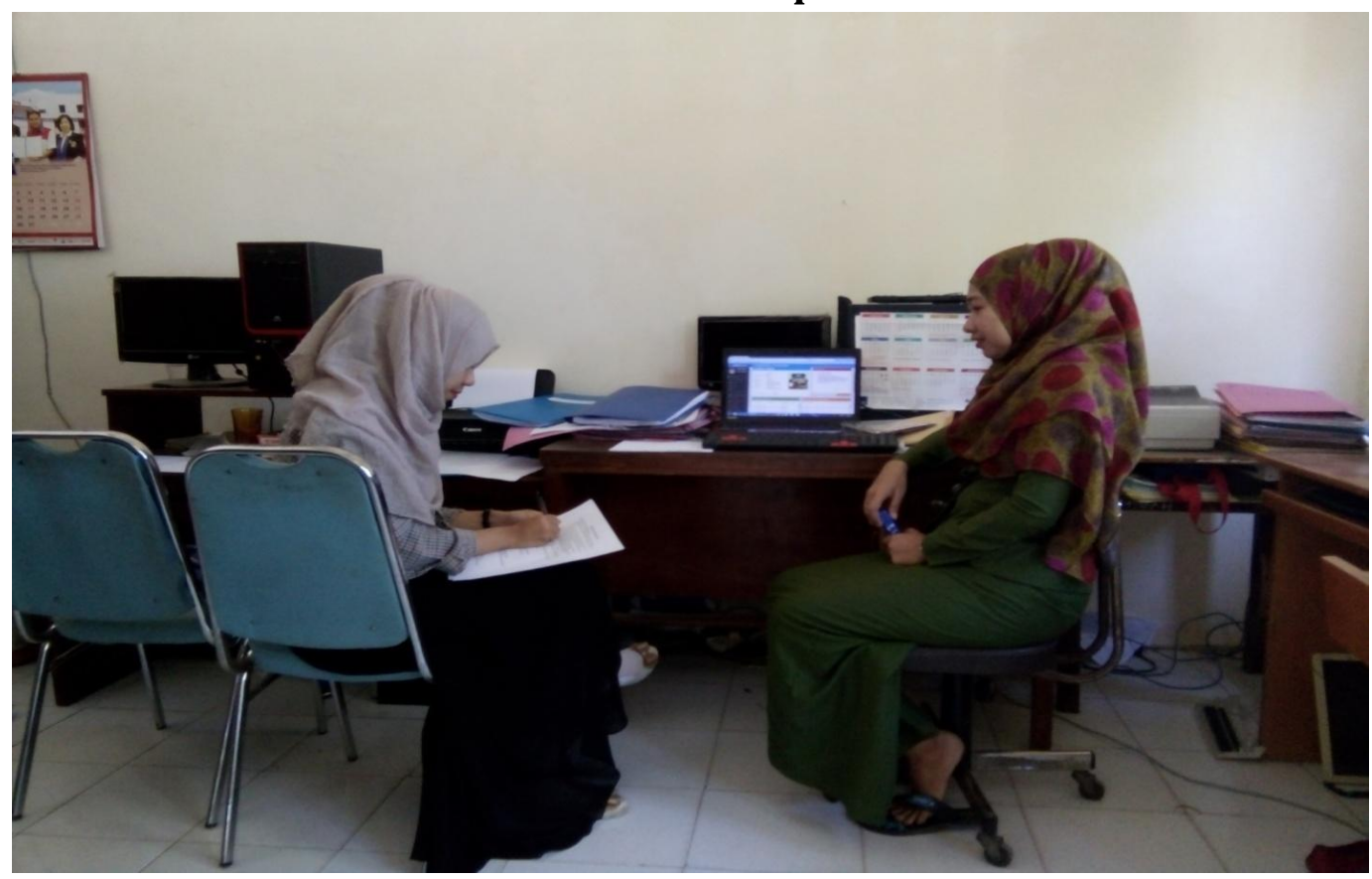

1. Bagian Pengumpulan Data

Dalam mengumpulkan data baik bersifat internal maupun eksternal. Data internal merupakan data yang berasal dari dalam organisasi sedangkan data eksternal merupakan data yang berasal dari luar organisasi akan tetapi masih terdapat hubungan dengan perkembangan organisasi.

Data internal dapat diperoleh dari semua unit kerja dalam organisasi yaitu dari wakasek, meliputi wakasek bagian pengajaran, kesiswaan, sarana prasarana dan humas. Ini berarti bahwa bidang-bidang fungsional dan berbagai satuan kerja dalam organisasi dapat menjadi sumber data. Sedangkan data eksternal dapat diperoleh dari lingkungan sekitar. Pengumpulan data secara ekternal harus disesuaikan dengan kondisi dan kebutuhan organisasi.

Operator sekolah bertugas pada pengumpulan data bahwa dalam pengumpulan data harus merencanaan data, menetapkan tujuan, jenis data dan waktu pengumpulan data sampai pada pengamanan data. Data dapat diambil dari seluruh unit kerja dalam organisasi yaitu dari wakasek bagian kesiswaan, pengajaran, sarana prasarana dan keuangan sehingga setiap unit kerja yang memiliki wakil-wakil akan menunjang keefektifan pengumpulan data untuk diolah menjadi sebuah informasi yang bermanfaat bagi pengguna informasi. Misalnya bagian kesiswaan meliputi data riwayat siswa, jenis kelamin, latar belakang orang tua dan sebagainya sedangkan bagian pengajaran meliputi pembuatan program tahunan dan semester dan perangkat pembelajaran yang akan dilakukan dalam satu semester, 
sedangkan bagian keuangan meliputi perencanaan keuangan, pelaksanaan keuangan (penerimaan dan pengeluaran). Sedangkan bagian sarana prasarana meliputi pengadaaan sarana prasarana, mengkoordinasikan pendayagunaan sarana prasarana sekolah.

\section{Gambar 4 \\ Proses Pengumpulan Data}

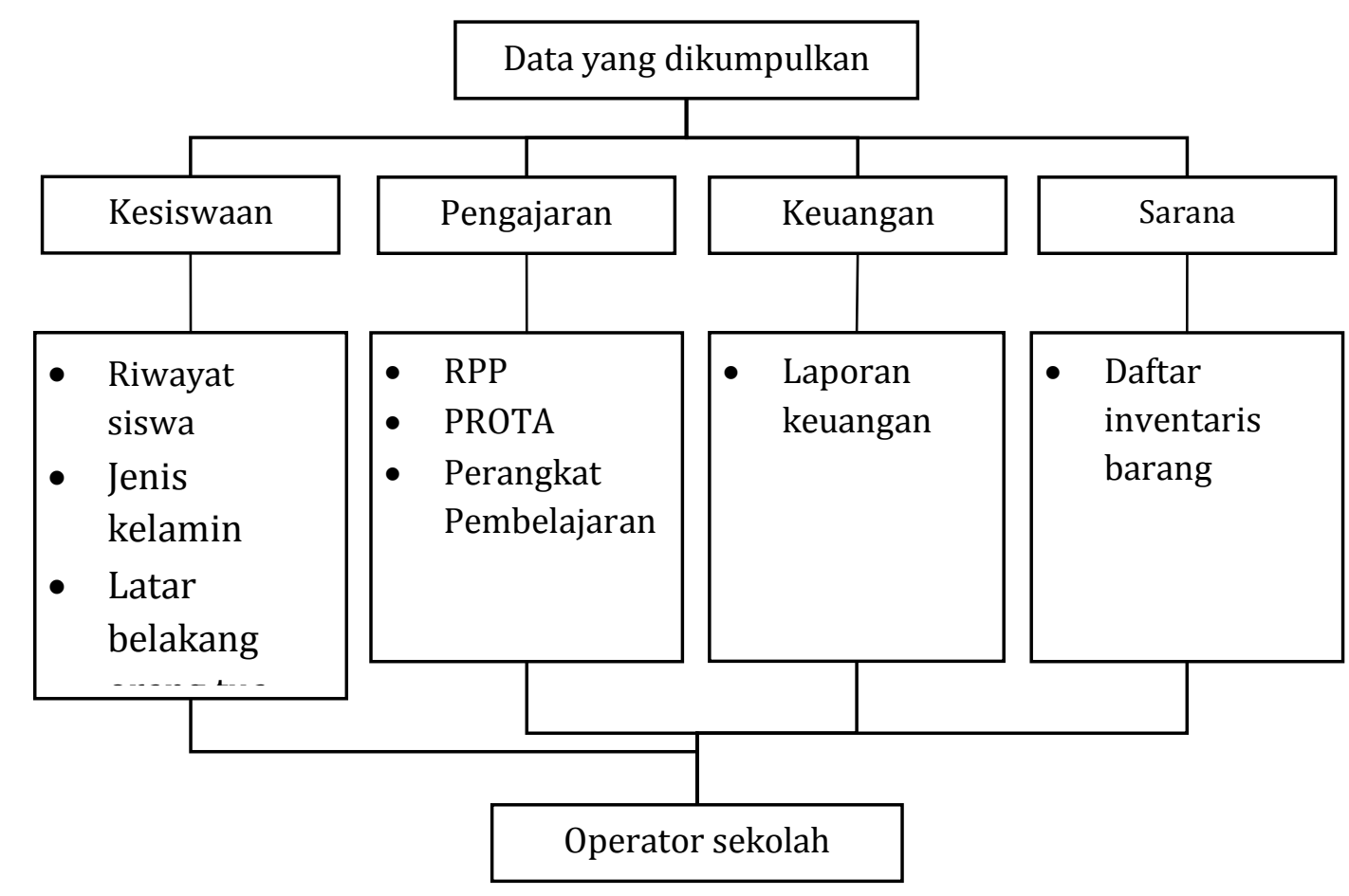

Dalam pengumpulan data masih terdapat kesalahan atau kendala yang didapat ketika data yang diinginkan segera dikumpulkan, dari unit kerja terlambat dalam pemberian datanya jadi ketika data yang ingin diinput terkadang kita berulangkali mengirimnya lagi. ${ }^{11}$

Dapat dikatakan bahwa data dapat diperoleh dari berbagai sumber dalam berbagai bentuk. Pada dasarnya data diperoleh dari fakta-fakta yang ada di lapangan. Fakta yang memiliki makna tertentu bagi pengembangan organisasi, maka fakta akan diklasifikasikan dan disusun menjadi data. Fakta yang dijadikan data adalah fakta yang memiliki nilai tertentu sesuai dengan kebutuhan organisasi dan akan menjadi informasi.

\footnotetext{
${ }^{11}$ Relawati, Tata Usaha SMA Negeri 1 Barru, Wawancara oleh peneliti, dalam Ruangan Tata Usaha, Barru, 02 September 2016
} 
Pada pengumpulan data dapat dikatakan berjalan baik dan normal apabila semua komponen sekolah atau seluruh unit kerja tepat waktu dalam pemberian data dan saling berkerja sama untuk mencapai tujuan organisasi.

2. Bagian Pengolahan Data

Program perencanaan pendidikan nasional merupakan salah satu bagian penting dalam proses mewujudkan rencana strategis pembangunan pendidikan nasional, yaitu peningkatan akses, mutu, tata kelola pendidikan nasional. Untuk membangun program perencanaan pendidikan yang valid, terukur dan berkesinambungan diperlukan data-data pendukung yang lengkap dan valid. Berdasarkan pada kebutuhan tersebut, program perencanaan pendidikan membangun sistem pendataan terbaru dimana proses transaksi datanya dilakukan dalam secara terpusat, online dan real time yang disebut dengan sistem dapodik.

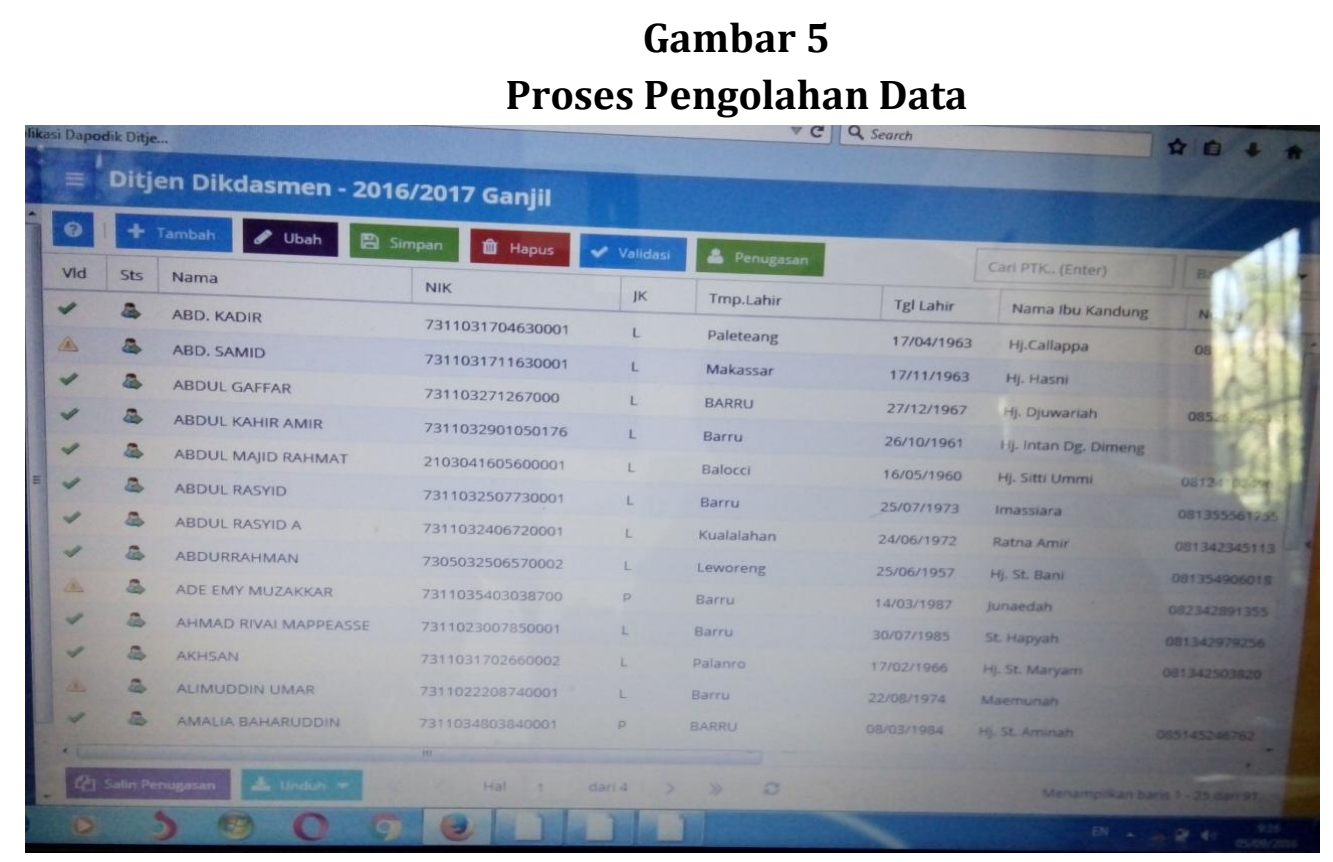

Dapodik adalah suatu sistem pendataan dan pegelolaan data-data pendidikan yang bersifat mikro secara online dan real time. Terdapat jenis data utama pendidikan yang dikelola pada sistem dapodik, meliputi data sekolah, data siswa, dan data guru/karyawan dsb.

Dapodik bertujuan untuk mewujudkan basis data sehingga dapat tercipta tata kelola data pendidikan yang terpadu dan menghasilkan data yang representatif untuk memenuhi kebutuhan kementrian dan pemangku kepentingan lainnya. Dan tujuan berikutnya adalah untuk mendukung peningkatan efisisensi, efektif, dan sinergi kegiatan pengumpulan data pokok yang terintegrasi dalam satu sistem pendataan.

Mengolah data dilakukan dengan mengikuti serangkaian langkah tertentu sehingga data di ubah ke dalam bentuk informasi yang lebih berguna 
dengan menggunakan perangkat komputer kemudian diinput melalui pengolah data yaitu dapodik. Dengan sistem pengolahan data melalui dapodik maka pengelolaan riwayat data sekolah, siswa, guru/karyawan lebih mudah diterintegrasikan dan disimpan secara terpusat dan dapat diakses dengan mudah dalam batasan tertentu melalui internet. Selain itu proses pemutakhiran data dapat dilakukan secara langsung online dan real time dengan memanfaatkan koneksi internet.

Dalam mengolah data dengan prosedur yang telah ditetapkan harus memastikan prosedur tersebut telah terbebas dari kesalahan Meliputi:

a. Koneksi peralatan pendukung untuk mengecek pendeteksian kode

b. Memastikan bahwa prosesor yang digunakan tidak terdapat kesalahan

c. Pengecekan terhadap kompatibilitas program sebelumnya dengan program baru yang digunakan

d. Ketersediaan prosedur. ${ }^{12}$

Dalam melakukan pencegahan kesalahan yang terjadi sehingga perlu disediakan prosedur pencegahan yang memberikan informasi tentang prosedur yang benar kepada operator dalam pengolahan data.

Dalam mengolah data juga harus dilakukan secara berkesinambungan karena dengan perkembangan waktu maka secara otomatis juga akan mengalami perubahan pada data untuk mengantisipasi perubahan data unit pengolah data harus selalu meng-up date data sesuai dengan kenyataan. ${ }^{13}$

Seiring dengan perkembangan waktu, secara otomatis fakta yang terjadi juga mengalami perkembangan. Hal ini akan berpengaruh pada datadata yang diperlukan. Untuk mengantisipasi perubahan data yang terjadi setiap waktu, unit pengolah data harus mengikuti dan meng-up date data sesuai dengan kenyataan, karena hal ini akan mempengaruhi informasi yang diterima manajer (kepala sekolah dan wakil-wakilnya) dan akan berdampak besar pada perkembangan organisasi.

Dengan demikian dapat disimpulkan bahwa pengolahan data dilakukan secara langsung online dan real time dengan memanfaatkan koneksi internet dan pengolahan data harus dilakukan secara terus menerus dan berkesinambungan dimana unit pengolah data harus mengikuti dan meng-up date data sesuai dengan kenyataan karena hal ini akan mempengaruhi informasi yang diterima manajer (kepala sekolah dan wakilwakilnya) dan akan berdampak besar pada perkembangan organisasi.

3. Bagian Penyimpanan Data

\footnotetext{
${ }^{12}$ Muh.Hidayat, Tata Usaha SMA Negeri 1 Barru, Wawancara oleh peneliti, dalam Ruangan Tata Usaha, Barru, 02 September 2016

${ }^{13}$ Relawati, Tata Usaha SMA Negeri 1 Barru, Wawancara oleh peneliti, dalam Ruangan Tata Usaha, Barru, 02 September 2016
} 
Bagian penyimpanan data bertugas menyimpan data. Penyimpanan data sangat diperlukan, karena tujuan utamanya adalah demi keamanan data. Apabila level-level manajemen membutuhkan data, baik data berupa bahan mentah maupun data yang telah diolah, maka data dapat diambil dan digunakan sesuai dengan kebutuhan manajer (kepala sekolah maupun wakilnya). Penyimpanan informasi sangat penting karena tidak semua informasi yang dimiliki digunakan saat sekarang tetapi sesuai dengan kebutuhan.

Untuk menjaga validitas data sekolah, siswa dan guru/karyawan pada sistem dapodik maka diterapkan sistem penomoran khusus yang berfungsi sebagai identitas tunggal yang berlaku seumur hidup dalam skala nasional. Sistem penomoran tersebut menjadi kunci utama dan demi keamanan data dari sistem dapodik. Oleh karena itu, terdapat 3 subprogram pada dapodik yaitu: NPSN (Nomor Pokok Sekolah Nasional), NISN ( Nomor Induk Siswa Nasional), dan NIGN ( Nomor Induk Guru Nasional). ${ }^{14}$

Nomor Induk Siswa Nasional (NISN) adalah kode pengenal siswa yang bersifat tunggal dan berlaku seumur hidup membedakan satu siswa dengan siswa lainnya. Penerapan kode pengenal siswa disetiap sekolah pada sistem dapodik dapat terjaga validitasnya.

Nomor Pokok Sekolah Nasional (NPSN) merupakan kode pengenal sekolah yang bersifat tunggal dan berlaku selama sekolah tersebut aktif. Kode terbaru ini disiapkan untuk menggantikan (NSS-Nomor Statistik Sekolah) yang dinilai sudah konsisten dan sangat rentan terhadap perubahan wilayah/daerah Indonesia. NPSN seluruhnya angka dengan jumlah 10 digit sehingga mudah dihafal atau dituliskan.

Nomor Induk Guru Nasional (NIGN) adalah kode pengenal guru/karyawan yang berlaku seumur hidup. Penerapan kode pengenal guru/karyawan yang berlaku secara nasional, maka data guru/karyawan pada sistem Dapodik dapat terjaga validitasnya.

Pada Implemetasinya, melalui pengolah data dapodik sekolah diberikan tanggung jawab dalam mengumpulkan data siswa, sekolah dan guru/karyawan dan mengoperasikan sistem dapodik yang telah disediakan dan melaporkan hasil kerja masing-masing.

Untuk menjaga keberlanjutan data siswa, sekolah/karyawan yang valid pada dapodik maka perlu dioptimalkan penggunaan NISN, NPSN dan NIGN sebagai salah satu syarat utama dalam pelaksanaan program kegiatan di depdiknas, meliputi: Bantuan Operasioanl Sekolah( BOS), Nomor ujian di

\footnotetext{
${ }^{14}$ Muh. Hidayat, Tata Usaha SMA Negeri 1 Barru, Wawancara oleh peneliti, dalam Ruangan Tata Usaha, Barru, 02 September 2016
} 
sekolah atau tingkat nasional, ujian masuk perguruan tinggi, beasiswa, statistik pendidikan, sertifikasi Guru/karyawan, dsb.

Kegiatan penyimpanan informasi sangat penting agar terjamin keamanannya, hemat biaya, serta mudah dicari dan diambil apabila diperlukan sewaktu-waktu. Selain dalam ingatan manusia penyimpanan informasi dapat dilakukan pada alat-alat seperti hard disk, flashdisk, dan sebagainya. ${ }^{15}$

Dapat disimpulkan bahwa pemanfaatan teknologi informasi sebagai alat penyimpanan informasi sehingga biaya penyimpanan lebih hemat, terutama karena tidak memerlukan tempat yang besar. Selain itu, dengan sarana teknologi tinggi, keadaan informasi lebih terjamin. Informasi yang telah terkumpul dan terolah dengan baik perlu disimpan dengan sebaik mungkin mengingat informasi sebagai salah satu sumber daya strategis dalam organisasi, maka penerapan kode dilakukan agar terjaga validitas data tersebut.

\section{PENUTUP}

Penerapan sistem informasi manajemen sangat penting di lembaga pendidikan khususnya di SMA Negeri 1 Barru dimana menggunakan aplikasi pengolah data yaitu dapodik dan teknologi informasi dalam mendukung proses pembelajaran memberikan layanan pendidikan dengan memfasilitasi praktek pembelajaran dengan menggunakan infrastruktur teknologi, seperti fasilitas belajar dengan memadukan computer.

Dalam mengimplementasikan sistem informasi manajemen dalam mendukung pelayanan administrasi di sekolah, tata usaha merupakan bagian terpenting dalam suatu sekolah yang bertugas mengkoordinir pada semua bagian dan bertanggung jawab langsung pada manajemen puncak/kepala sekolah yang meliputi bagian pengumpulan data, bagian penginputan data, bagian penyimpanan data, semuanya itu dikerjakan oleh tata usaha khususnya operator sekolah. Sehingga dapat dikatakan bahwa dalam suatu pendidikan atau suatu sekolah tidak dapat mencapai suatu tujuan yang diinginkan tanpa adanya sumbangsi dari tenaga tata usaha.

Oleh karena itu, diharapkan kepada pihak sekolah SMA Negeri 1 Barru dapat meningkatkan pelayanan secara kreatif dan inovatif serta mengimplementasikannya secara efektif dan efesien. Dalam memberikan informasi agar lebih cepat dan akurat yang merupakan bagian dari kualitas pelayanan, sehingga akan mengoptimalkan pelaksanaan program disekolah.

\footnotetext{
${ }^{15}$ Relawati, Tata Usaha SMA Negeri 1 Barru, Wawancara oleh peneliti, dalam Ruangan Tata Usaha, Barru, 02 September 2016
} 


\section{4 | Musdalifah, Nasir Mahmud, Kasmawati}

Terakhir, hendaknya sekolah mendesain segala hal yang berhubungan dengan kebutuhan siswa di sekolah sesuai dengan pekembangan zaman yang menyediakan program layanan siswa yang mudah dicapai dan lengkap.

\section{DAFTAR PUSTAKA}

Handoko, T. Hani, Manajemen, Yogyakarta: BPFE-Yogyakarta, 1999.

Rochaety, Eti, dan Pontjorini Rahayuningsih, Prima Gusti Yanthi, Sistem Informasi Manajemen Pendidikan, Jakarta: Bumi Aksara, 2006.

Rochaety, Eti, dkk., Sistem Informasi Manajemen Pendidikan, Jakarta: Bumi Aksara, 2006.

Sarwono, Sarlito W., Psikologi Remaja (Cet. XIII), Jakarta: Raja Grafindo, 2010.

Sutrisno, Oteng, Administrasi Pendidikan, Bandung: Angkasa, 1985. 